\title{
BOTANICA MARINA
}

$2020 \cdot$ JUNE · VOLUME 63 - NUMBER 3 - PAGES 209-298

\section{EDITOR-IN-CHIEF}

Matthew J. Dring, Belfast/Portaferry, Northern Ireland (-2020)

\section{ASSOCIATE EDITORS}

Roger Huerlimann, Townsville, Australia (-2023)

Ka-Lai Pang, Keelung, Taiwan (-2020)

Michel Poulin, Ottawa, Canada (-2020)

Thomas Wichard, Jena, Germany (-2022)

\section{EDITORIAL BOARD}

Charles D. Amsler, Birmingham, USA (-2020)

Inka Bartsch, Bremerhaven, Germany (-2022)

John A. Berges, Milwaukee, USA (-2020)

Sung Min Boo, Daejeon, Korea (-2022)

Olivier De Clerck, Ghent, Belgium (-2022)

Jeffrey L. Gaeckle, Olympia, USA (-2022)

Kirsten Heimann, Adelaide, Australia (-2022)

Mona Hoppenrath, Wilhelmshaven, Germany (-2020)

Catriona Hurd, Hobart, Australia (-2022)

Frithjof Kuepper, Aberdeen, Scotland, UK (-2020)

Gavin W. Maneveldt, Bellville, South Africa (-2022)

Georg Pohnert, Jena, Germany (-2022)

Dagmar Stengel, Galway, Ireland (-2024)

Michael J. Wynne, Ann Arbor, USA (-2020) 
ABSTRACTED/INDEXED IN AGRICOLA (National Agricultural Library) · Baidu Scholar · CABI (over 50 subsections) · Celdes · Chemical Abstracts Service (CAS): CAplus; SciFinder · CNKI Scholar (China National Knowledge Infrastructure) · CNPIEC · EBSCO (relevant databases) · EBSCO Discovery Service - Elsevier: BIOBASE/CABS (Current Awareness in Biological Sciences); Fluidex; Geobase; SCOPUS · Gale/Cengage · Genamics JournalSeek · Google Scholar · J-Gate · JournalTOCs · Naviga (Softweco) · NISC SA: Fish and Fisheries Worldwide · NISC SA: Water Resources Worldwide · Primo Central (ExLibris) $\cdot$ ProQuest (relevant databases) $\cdot$ ReadCube $\cdot$ ResearchGate $\cdot$ SCImago (SJR) $\cdot$ Summon (Serials Solutions/ProQuest) $\cdot$ TDOne (TDNet) · TEMA Technik und Management · Thomson Reuters: Biological Abstracts; BIOSIS Previews; Current Contents/Agriculture, Biology, and Environmental Sciences; Journal Citation Reports/Science Edition; Science Citation Index; Science Citation Index Expanded; Zoological Record · Ulrich's Periodicals Directory/ulrichsweb · WorldCat (OCLC)

The publisher, together with the authors and editors, has taken great pains to ensure that all information presented in this work (programs, applications, amounts, dosages, etc.) reflects the standard of knowledge at the time of publication. Despite careful manuscript preparation and proof correction, errors can nevertheless occur. Authors, editors and publisher disclaim all responsibility for any errors or omissions or liability for the results obtained from use of the information, or parts thereof, contained in this work.

The citation of registered names, trade names, trademarks, etc. in this work does not imply, even in the absence of a specific statement, that such names are exempt from laws and regulations protecting trademarks etc. and therefore free for general use.

ISSN 0006-8055 · e-ISSN 1437-4323 · CODEN BOTNA7

All information regarding notes for contributors, subscriptions, Open access, back volumes and orders is available online at www.degruyter.com/bm.

RESPONSIBLE EDITOR Prof. Matthew J. Dring, Queen`s University Marine Laboratory, Portaferry, Co. Down, BT22 1PF, Northern Ireland, UK, Tel: +44 2892-699526, Fax: +44 28427-28902, Email: m.dring@qub.ac.uk

JOURNAL MANAGER Dr. Gunda Stöber, De Gruyter, Genthiner Straße 13, 10785 Berlin, Germany, Tel.: +49 (0)30 260 05-279, Fax: +49 (0)30 260 05-298, Email: bot.mar.editorial@ degruyter.com

RESPONSIBLE FOR ADVERTISEMENTS Claudia Neumann, De Gruyter, Genthiner Straße 13, 10785 Berlin, Germany. Tel.: +49 (0)30 260 05-226, Fax: +49 (0)30 260 05-264, Email: anzeigen@ degruyter.com

(C) 2020 Walter de Gruyter GmbH, Berlin/Boston

TYPESETTING Compuscript Ltd., Shannon, Ireland

PRINTING Franz X. Stückle Druck und Verlag e.K., Ettenheim

COVER ILLUSTRATION Shallow-water kelp forest in Nova Scotia, Canada; photograph courtesy of Dr. Annelise S. Chapman.






\section{Contents}

\section{Physiology and ecology}

Ivana Zubak, Hrvoje Cizmek and Melita Mokos

Posidonia oceanica lower depth limits along a latitudinal gradient in the eastern Adriatic Sea -209

Laura Sordo and Paulo Lana

Temporal variations of Halodule wrightii meadows and associated fauna near their southern distribution limit in the southwestern Atlantic — 215

\section{Taxonomy/phylogeny and biogeography}

Cornelis den Hartog and Ludwig Triest

A profound view and discourse on the typification and status of three confused taxa: Ruppia maritima, $R$. spiralis and $R$. cirrhosa 229

Marion A. Wolf, Alessandro Buosi and Adriano Sfriso First record of Acanthosiphonia echinata (Rhodomelaceae, Rhodophyta) in the Mediterranean Sea, molecular and morphological characterization — 241

Yuichi Hayashi, Masahiro Notoya and Norishige Yotsukura

Abnormal asexual reproduction of thalli of Ecklonia stolonifera (Laminariales, Phaeophyceae) off the coast of Nakanoshima in the Oki Islands, Japan — 247

\section{Genomics}

Angela G. Bartolo, Gabrielle Zammit, Akira F. Peters and Frithjof C. Küpper

The current state of DNA barcoding of macroalgae in the Mediterranean Sea: presently lacking but urgently required -253

\section{Chemistry and applications}

Yuhi Satoh, Shigeki Wada and Shun'ichi Hisamatsu Relationship between iodine and carbohydrate contents in the seagrass Zostera marina on the northwestern Pacific coast of central Japan -273

Nuno Nunes, Sofia Valente, Sónia Ferraz, Maria Carmo Barreto and Miguel A.A. Pinheiro de Carvalho Biochemical study of attached macroalgae from the Madeira Archipelago and beach-cast macroalgae from the Canary Islands: multivariate analysis to determine bioresource potential -283 